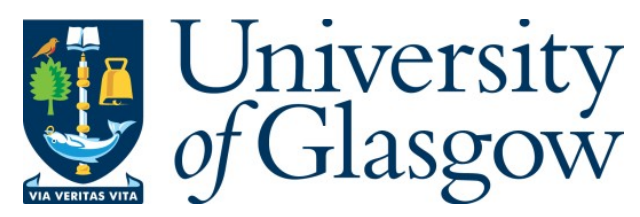

Dietrich, N., Jimenez, M., Souto, M., Harrison, A. W., Coudret, C. and Olmos, E. (2021) Using pop-culture to engage students in the classroom. Journal of Chemical Education, 98(3), pp. 896-906.

(doi: 10.1021/acs.jchemed.0c00233)

This is the Author Accepted Manuscript.

There may be differences between this version and the published version. You are advised to consult the publisher's version if you wish to cite from it.

https://eprints.gla.ac.uk/232928/

Deposited on: 29 January 2021

Enlighten - Research publications by members of the University of Glasgow http://eprints.gla.ac.uk 


\section{USING POP-CULTURE TO ENGAGE STUDENTS IN THE 2 CLASSROOM}

3

4

\author{
Nicolas DIETRICH¹, Mélanie JIMENEZ², Manuel SOUTO ${ }^{3}$, Aaron W. HARRISON,
} Christophe COUDRET 5 \& Eric OLMOS 6

1. Toulouse Biotechnology Institute (TBI), Université de Toulouse, CNRS, INRA, INSA, Toulouse, France

2. Biomedical Engineering Division, James Watt School of Engineering, University of Glasgow, Glasgow, United Kingdom

3. CICECO-Aveiro Institute of Materials, Department of Chemistry, University of Aveiro, Aveiro, Portugal

4. Schmid College of Science and Technology, Chapman University, Orange, California, USA

5. Interactions Moléculaires et Réactivité Chimique et Photochimique (IMRCP), Université de Toulouse, CNRS, UPS, Toulouse, France.

6. Laboratoire Réactions et Génie des Procédés (LRGP), Université de Lorraine, CNRS, LRGP, Nancy, France

\section{- ABSTRACT}

Herein, we describe how video games, TV shows or movies have been used to provide an innovative framework for students to think about chemistry and chemical engineering. The main objective of this paper is to show how science can be linked with pop culture, to provide educators with recent materials to use in classrooms, and to discuss the benefits and limitations of such tools. The videogames Fortnite, Spiderman and Angry Birds, the TV shows Game of Thrones and Breaking Bad, the Marvel movies, and the animated programs Raving Rabbids and Dragon Ball are used to illustrate different approaches to engage with students and encourage them to learn in a more recreational environment.

- GRAPHICAL ABSTRACT

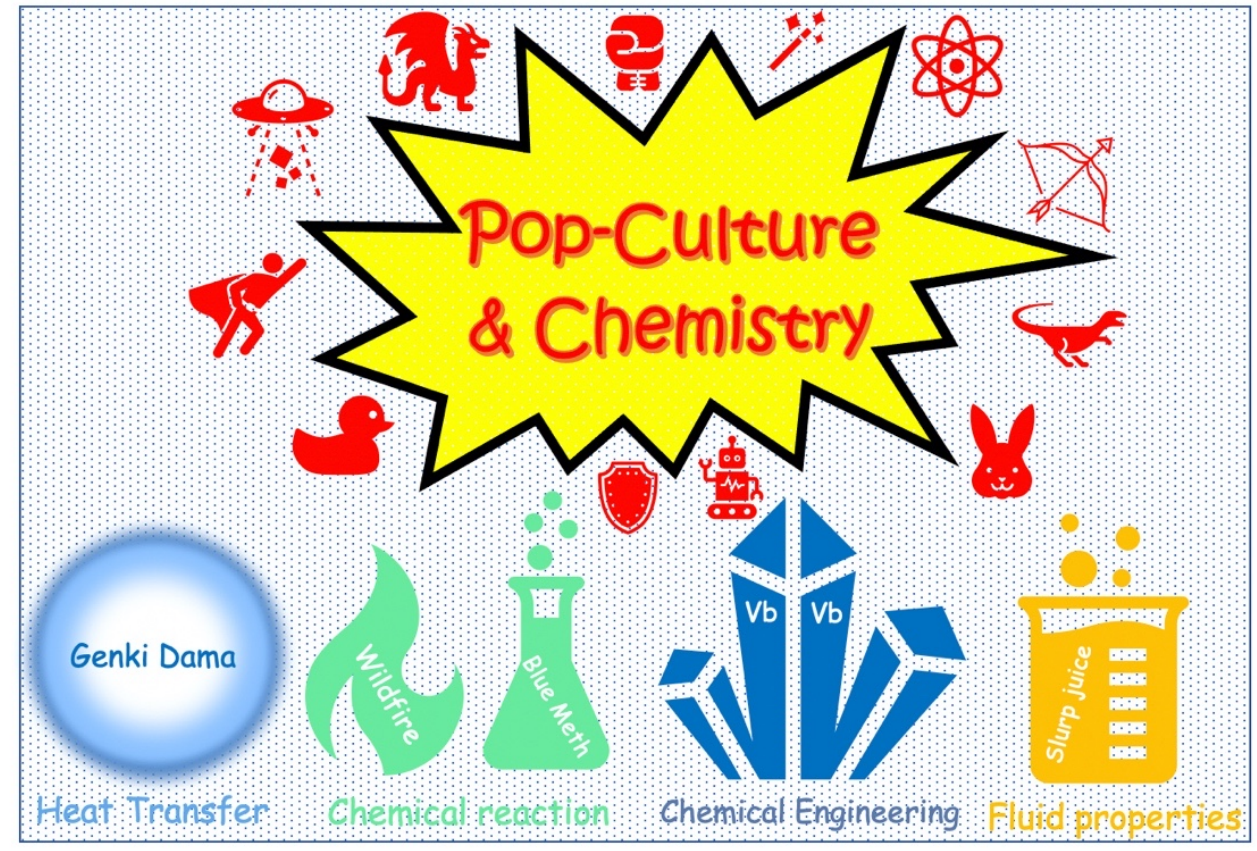

\section{- KEYWORDS}

General Public, Chemical Engineering, Collaborative / Communication / Writing, Humor / Puzzles / Games, Reactions / History, Philosophy/ Inquiry-Based/Discovery Learning, Physical Properties, Student-Centered Learning 
32 Attracting a general audience to chemistry and chemical engineering topics is a significant challenge ${ }^{1,2}$ and developing stimulating, alternative teaching methods is important for educators in all disciplines. In several articles, authors describe aspects of popular culture ${ }^{3}$ to teach chemistry using resources that are part of everyday life to engage students more effectively. Chemistry classes have been supplemented with material from arts such as music ${ }^{4-7}$ (including jazz ${ }^{8}$ and opera ${ }^{9,10}$ ) and paintings ${ }^{11-13}$ (including fashion $\operatorname{art}^{14}$ ), history ${ }^{15-18}$, archaeology ${ }^{19-21}$, or literature $22-27$. As examples, educators illustrated chemistry with a Shakespeare's play28 while others found inspiration in detective cases where chemistry was used by the perpetrator of a crime or in their identification ${ }^{29,30}$. The chemical references from Ian Fleming's James Bond ${ }^{31}$ series of novels were used to illustrate chemical reactions and substances (sedatives, rocket fuels, etc.). The Harry Potter novel series also offered an opportunity to reproduce wizardry experiments ${ }^{32}$ in a chemistry lab (e.g. with invisible and color-changing inks, colored flame in a jam-jar). Famous characters from the Sherlock Holmes stories (from Conan Doyle's novels) have been used to create a fictional mystery based on chemistry ${ }^{33-35}$, as has a murder novel of Agatha Christie ${ }^{36}$. Michael Crichton's novel Jurassic Park ${ }^{37}$ has been an inspiring source of discussions on the chemical defense of plants or chemicals used by animals for communication. Cartoons 38,39 and comic books ${ }^{40}$ can also illustrate chemical principles (e.g. microscale chemistry in Archie's comic book ${ }^{41}$ or general chemistry in Dick Tracy ${ }^{42-45}$, DC Comics ${ }^{46}$ or Marvel comics ${ }^{40}$ ). Recently, lab safety rules have been presented to students with comics ${ }^{47}$, graphic novels and mangas ${ }^{48}$. Beyond novels and comics, movies are currently one of the biggest providers of pop-culture ${ }^{49,50}$. The list of movies used to illustrate chemistry is impressive, including for example Apollo 1351, October Sky ${ }^{52}$, Star Trek ${ }^{53}$ and many others ${ }^{54-58}$. The omnipresent Marvel franchises often invoke various areas of chemistry and chemical engineering such as nanotechnology in the suits of Iron Man ${ }^{40}$, properties of the fictional metal vibranium in Black Panther 59 , the quantum realm in Ant-Man 60 , or material sciences in Spider-Man ${ }^{61}$. Television is also a good way to illustrate chemistry ${ }^{62}$ 
and famous shows used for this purpose include The Price is Right63, The Big Bang Theory ${ }^{64}$, CSI ${ }^{65}$, The Simpsons ${ }^{66}$, Bones $^{67}, E R$ and House ${ }^{68}$. Trending games ${ }^{69-89}$ are also an interesting pathway to involve students in general chemistry courses ${ }^{90-97}$. Educators have included pop-culture elements to solve educational escape games, e.g. to unveil the name of a super hero (Clark Kent from Superman) or famous gimmicks of a character 88,98 such as "Bazinga" from the TV series The Big Bang Theory. Moreover, while many educators have successfully used pop-culture themes to introduce their students to scientific concepts, educators have continually tried to use new techniques to engage their students, such as the creation of a Science Café on the pop-culture theme ${ }^{99}$. Video games ${ }^{100}$ have become an increasingly important part of the entertainment industry, and they are also considered a form of art ${ }^{101}$; surprisingly the use of videogames to illustrate chemistry or chemical engineering ${ }^{102}$ is relatively unexplored in the literature even though pedagogical videogames exist ${ }^{103-105}$. Video games being used directly in education is an increasingly popular research topic and even just playing commercial video games has been shown to benefit important skills in adult learners like effective communication, executive function, and resourcefulness ${ }^{106-}$ 108. Though these examples have been focused on skills-based learning, using video games for content-based learning in chemistry such as described below is beginning to be explored. The most notable example can be seen in the recent work by Smaldone, et al. where the authors presented a modified version of the popular video game Minecraft called PolyCraft World. In the game, the player collect resources and uses chemical refinement and synthesis techniques to craft equipment and materials in the game ${ }^{109}$. Initial results indicated that students who played the game learned advanced chemistry even without grading incentive or traditional classroom instruction. Given the difficulty of creating an engaging game content de novo, finding existing popular games to modify or for insight into how games can be used for educational purposes like PolyCraft World is an important resource. The main objective of this paper is to explore recent popculture references and the untapped potential of videogames for teaching purposes and more broadly propose new approaches to link chemistry/chemical engineering and pop 
culture. We present a range of activities inspired by videogames but also TV shows and recent movies, with their context and materials for implementation by the wider community. In a first section, three different activities that have been applied with students will be presented and the feedbacks from students' are discussed; in a second section, some additional activities used for outreach events are described.

\section{ACTIVITIES}

We report here activities related to the videogames Fortnite, the TV shows Games of Thrones and Breaking Bad and the movie Black Panther. All these activities were tested and evaluated with students' (see supplementary information for more details about the activities).

100 Fortnite is an online video game developed in 2017 by Epic Games. The game mode includes a free-to-play battle royale game where up to 100 players fight in increasingly smaller spaces to be the last person standing. The game has cartoon graphics and does not present graphic violence such as bloodshed. Fortnite Battle Royale became a resounding success, drawing in more than 125 million players in less than a year and earning hundreds of millions of dollars per month. In early 2018, students of Tippecanoe High School in Ohio, USA, used a social media platform to challenge their professor to have a Fortnite-based final exam in chemistry. Although there is no report on how this story ended, it motivated the authors of this article to develop a new Fortnite-based protocol for chemistry classes that could be used by teachers facing a similar situation.

111 The videogame Fornite is more oriented toward physics than chemistry (e.g. bullet

112 and rocket trajectories, amount of force per impact of projectiles, etc.). Nevertheless, in

113 the game, once players have landed on the map, they must scavenge for weapons, 114 resources and other items. The objective of this activity is to reproduce in the lab 115 several items present in the Fortnite video game to illustrate simple chemical reactions.

116 One of these items is the "slurp juice", a consumable that adds shield and health points 117 to the character. This item is represented by a two-colored viscous fluid with beads in a 
118 jar, which could be prepared in the chemistry lab with a teacher. The fluids can be

119 made as slime paste using common material (hot water, a spoonful of borax, and glue)

120 or chemical products (water, polyvinyl alcohol, and boric acid) in order to illustrate the

121 mechanism of polymerization of polyvinyl alcohol110. This activity is recommended for

122 middle school students', high school students' or even for beginners in chemistry at

123 University level. Materials and methods for this activity are detailed in the

124 supplementary information. Some glass beads and dyes (green for the bottom fluid and

125 blue for the top fluid) can be added after the polymerization in order to improve the

126 resemblance to the "real" slurp juice as depicted in Figure 1.a. The polymer unique

127 properties (of both a solid and a liquid) can first be discussed in the classroom. Then

128 experiments can be planned to answer the following questions:

129 i) How can you make the polymer stretch the farthest?

130 ii) Does the amount of borax added change the slime structure?

131 iii) What method of storage will make the polymer last the longest?

132 iv) What brand of glue makes the stretchiest polymer?

133 v) Does the amount of water added to the glue affect the gooeyness of the 134 potion?

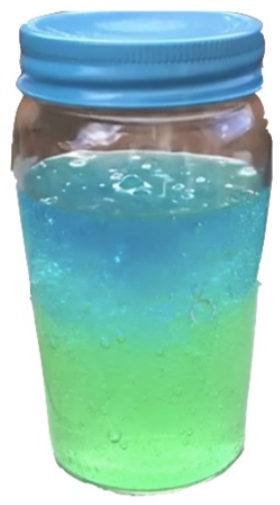

(a)

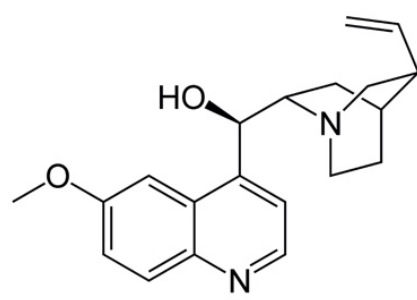

(b)

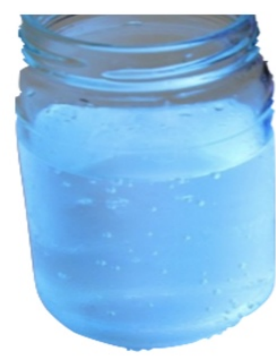

(c)

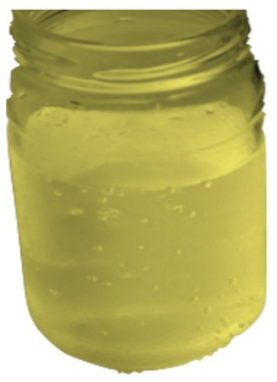

(d) 
137 A second famous item in the game is the "shield potion", a glowing blue liquid in a jar

138 with gems floating inside. This item can be easily made using tonic water and a black

139 light. The quinine (Figure 1.b) in tonic water will glow blue $111-113$, and the carbonic 140 bubbles can perfectly mimic the gems (Figure 1.c). This experiment highlights the 141 phosphorescence properties of quinine but fluorescein could also be used to show 142 fluorescence effects ${ }^{114}$. Other products, such as energy drinks with B vitamins, milk, 143 vanilla ice cream, caramel, and honey (to give a yellow color) could be used to produce a 144 "stink bomb" (Figure 1.d) by adding few spoonfuls of table vinegar and hydrogen 145 peroxide or directly with luminol to illustrate chemiluminescence $115-117$. The "stink 146 bomb" can also illustrate chemical reaction and gas-liquid equilibrium as it is composed 147 of ammonium hydrosulfide $\left(\mathrm{NH}_{4} \mathrm{SH}\right)$, an unstable compound that decomposes into 148 ammonia and hydrogen sulfide. As soon as the container is broken (open), the dissolved 149 ammonium sulfide rapidly decomposes and liberates copious amounts of the pungent 150 gas.

\section{GAME OF THRONES}

152 Game of Thrones is an American fantasy drama television series created by David

153 Benioff and D. B. Weiss for HBO in 2011118. It is an adaptation of A Song of Ice and Fire,

154 George R. R. Martin's series of fantasy novels, the first of which is A Game of Thrones, 155 first published on August 1, 1996119. "Blackwater" is the ninth and penultimate episode 156 of the second season of HBO's medieval fantasy television series. The entire episode is 157 dedicated to the climactic Battle of the Blackwater, in which the Lannister army, 158 commanded by acting Hand of the King, Tyrion Lannister, defends the city of King's 159 Landing. This episode is famous for its epic wildfire explosion during the Battle of 160 Blackwater Bay. In the series, wildfire is a flammable liquid that is created and 161 controlled by an Alchemist's Guild. When ignited, it can explode with tremendous force 162 and the resulting fire cannot be extinguished with water. Wildfire is identifiable by the 163 distinctive green hue of its flames and a bright green color in its liquid state.

164 The objective of this activity is to reproduce the flame. This activity is recommended as 165 a demonstration only for high school or university students' but the wildfire must be 
166 made in the lab only by the educator with screen protection and a safety disclaimer 48,120

167 (see hazard section).

169 When mixing boric acid with methanol; the reaction occurring is the synthesis of 170 trimethyl borate, $\mathrm{B}\left(\mathrm{OCH}_{3}\right)_{3}$ depicted in Figure 2.a, and is as follows:

$$
\mathrm{H}_{3} \mathrm{BO}_{3}+3 \mathrm{CH}_{3} \mathrm{OH} \rightarrow \mathrm{B}\left(\mathrm{OCH}_{3}\right)_{3}+3 \mathrm{H}_{2} \mathrm{O}
$$

172 Trimethyl borate burns distinctively green, as represented in Figure 3.a, due to the 173 presence of boron:

$$
4 \mathrm{~B}\left(\mathrm{OCH}_{3}\right)_{3}+21 \mathrm{O}_{2} \rightarrow 4 \mathrm{BO}_{3}+12 \mathrm{CO}_{2}+18 \mathrm{H}_{2} \mathrm{O}
$$

175 The experiment can be carried out with common products such as gas line antifreeze (methanol) and laundry booster/cleaning agent (borax - sodium borate) although this gives a mixture of orange and green flames due to the presence of sodium with the

178 borate. This experimentation could be completed with the flame test to discuss the effect of ion on the flame color ${ }^{121}$, as done for the older pop culture reference Harry Potter $^{32}$. More information about the experiment is given in the supplementary section.

\section{BREAKING BAD}

Breaking Bad, a crime drama television series created by Vince Gilligan in $2008^{122}$ for AMC, also offers numerous opportunities for use in classroom. The chemist protagonist, Walter White, chooses to stop using his chemistry skills to teach for an immoral world of drugs, death, destruction and destabilization ${ }^{123}$. In order to promote the positive value of chemistry, we hereby propose having students work on a similar but useful molecule, dextroamphetamine. Unlike the methamphetamine in Breaking Bad,

190 dextroamphetamine is a central nervous system stimulant that is prescribed for the 191 treatment of attention deficit hyperactivity disorder and narcolepsy ${ }^{124}$. The synthesis of 192 this molecule is depicted in Figure 2.b. The proposed activity for organic or chemical engineering students is, like the main character of the series, to build the chemical

194 process on paper from the raw data (solubility in water, boiling point, fusion point, 195 reaction enthalpy, etc.) as depicted in the supplementary section. This activity is 


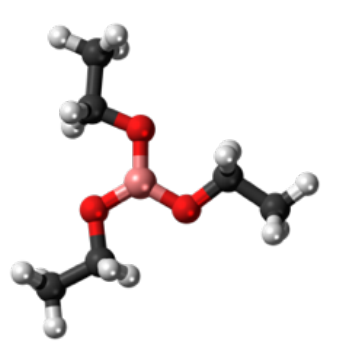

(a)

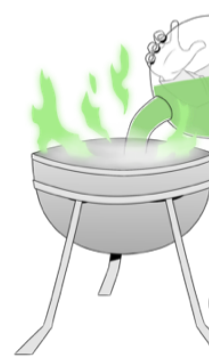

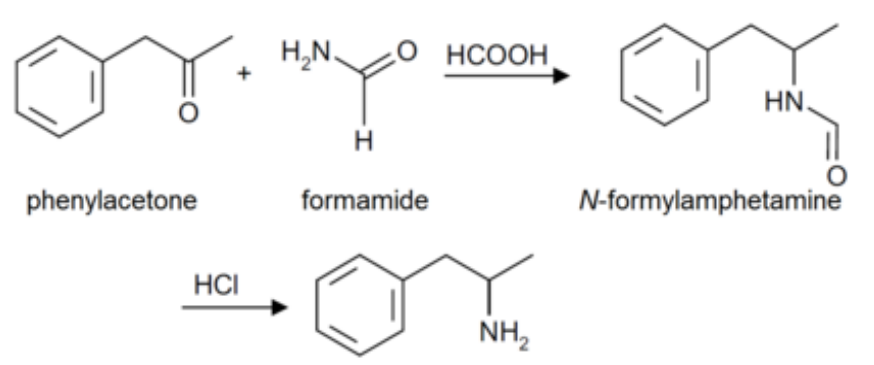

amphetamine

Figure 2. (a) The triethyl borate molecule and an illustration of the "green fire" reaction from Game of Thrones (b) Synthesis of the dextroamphetamine Many other references from this series can be used for illustration, such as the reaction of hydrofluoric acid with silicon material (bath tube), the chemical composition of the human body $(63 \%$ hydrogen, $26 \%$ oxygen, $9 \%$ carbon, $1.25 \%$ nitrogen, $0.04 \%$ sodium, $0.25 \%$ of calcium, $0.00004 \%$ iron and $0.19 \%$ phosphorus), chirality of molecules and its possible consequences (such as Thalidomide ${ }^{125,126}$ ), explosives, and ricin poisons ${ }^{127}$. As discussed later, an activity with such a controversial series must be well supervised by educators.

\section{BLACK PANTHER}

Movies are the pop culture medium that is most widely used to illustrate science and chemical concepts, especially science fiction and superhero movies. Black Panther has been used recently to encourage students to think about an imaginary element, called Vibranium 59 . In the movie, Wakanda's economy focuses on the production and use of this element, which has extraordinary chemical and physical properties. In this activity, the students were questioned on the possible place of Vibranium in the periodic table and its properties. The students' were separated in several groups and have to build a product with this element. A majority of the students developed a process to build the Vibranium steel, based on classical steel production (depicted in the supplementary section) whereas only very few groups worked on super-plastics or super-fertilizers based on vibranium. This overwhelming representation of steel production must be due 
219 to the influence of the movie, then an idea to avoid this behavior could be to impose a 220 different product for each group, or to ask students for an alternative to the steel 221 application. This activity is recommended as a project support or a discussion for 222 university students' in chemistry or chemical engineering. The periodic table is a 223 chemical concept that is easy to link with pop culture, and a large number of films 224 include an element in their title56. Many fictional elements are also present in the 225 movies $^{128}$ (Table 1). As an activity for students, they could be asked to find an 226 occurrence in a movie of a real or a fictional element and to discuss the properties of 227 both, and to develop their creativity by linking these elements with the Mendeleev 228 periodic table. Having a strong knowledge of the periodic table is also fundamental to 229 understand the basic principles of chemistry and different strategies and games have 230 been proposed to help students memorize the position of each element in the periodic 231 table ${ }^{129,130}$. Recently, different periodic tables have been designed using fictional 232 characters to be used as a mnemonic for high school students. For example, Disney 233 characters have been organized in the periodic table relating each character to a 234 property of the element (i.e. Boron $(\mathrm{B})=$ Bambi, Bambi was Disney's fifth movie) ${ }^{131}$ 235 whereas Marvel, DC and Asterix characters have been periodically distributed in the 236 periodic table by choosing characters whose names are reminiscent of the elements (i.e. 237 Magnesium $(\mathrm{Mg})=$ Magneto) ${ }^{132,133}$. This can be also an activity to be carried out in class 238 where each student could choose other pop culture characters (i.e. The Simpsons, Star 239 Wars) or popular public figures (i.e. soccer players, rock stars) they like best in order to 240 organize them in the periodic table according to their properties and/or names. Besides 241 being a strategy to increase the attention of younger students for introducing the 242 periodic table in classroom, relating the elements of the periodic table to pop culture 243 characters is a very useful strategy to help memorize the groups and periods as well as 244 to explain the properties of each element.

Table 1. List of fictional elements present in pop-culture media

\begin{tabular}{|l|c|c|}
\hline Name & $\begin{array}{c}\text { Assumed } \\
\text { Symbol }\end{array}$ & Reference \\
\hline
\end{tabular}




\begin{tabular}{|c|c|c|}
\hline Adamant & Ad & $\begin{array}{c}\text { The Lord of the Rings (books, movie), Final Fantasy } \\
\text { (videogame) }\end{array}$ \\
\hline Adamantium & Am & Marvel Comics (comic book) \\
\hline Bavarium & Ba & Just Cause 3 (videogame) \\
\hline Bolognium & Bo & The Simpsons, Futurama (TV shows) \\
\hline Dilithium & $\mathbf{D i}$ & Star Trek (movie and series) \\
\hline Divinium & $\mathbf{D v}$ & Call of Duty series (videogame) \\
\hline Duranium & $\mathbf{D u}$ & Star Trek (movie and TV series) \\
\hline Feminum & $\mathbf{F m}$ & Wonder Woman (comic book) \\
\hline Jerktonium & $\mathbf{J e}$ & SpongeBob SquarePants (TV animation show) \\
\hline Kryptonite & $\mathbf{K y}$ & DC Comics (comic book) \\
\hline Mithril & $\mathbf{M i}$ & Terraria/Final Fantasy (videogames) \\
\hline Redstone & $\mathbf{R e}$ & Minecraft (videogame) \\
\hline Saronite & $\mathbf{S a}$ & World of Warcraft (videogame) \\
\hline Transformium & $\mathbf{T r}$ & Transformers: Age of Extinction (movie) \\
\hline Valeryan & $\mathbf{V a}$ & Game of Thrones (TV series) \\
\hline Vibranium & $\mathbf{V b}$ & Marvel Comics (comic book) \\
\hline
\end{tabular}

251 Boric acid can be irritating for the eyes, skin, nose, throat and lungs, so it is 252 recommended to wear rubber gloves when handling cleaning products, to wash away 253 any cleaning product with water, and to avoid contact with nose, mouth, and eyes. 254 Boric acid is classified as toxic to reproduction and should not be handled by students. 255 The reaction involves fire therefore it should be conducted by a trained person in a safe 256 area with a use of a protection shield. Prepare a lid to cover the container in order to 257 quench the fire. Do not attempt to refill the container during or after the experiment. 258 Methanol can cause metabolic acidosis, neurologic sequelae, and even death, when 259 ingested, so it is recommended to wear rubber gloves when handling cleaning products, 260 to wash away any cleaning product with water, and to avoid contact with the nose, 261 mouth, and eyes. Personal protective equipment such as dust mask, eyeshields, face 262 shields and gloves should be used for the manipulation of the resazurin dyes.

\section{- STUDENT'S EVALUATION AND DISCUSSION} Students from three separate courses used these activities ("Fortnite", "Game of Throne", "Breaking Bad" and the "Black Panther") after attending a series of lectures (10 h) covering the topic of chemical engineering. The first two activities were used as a demonstration tool while the last two were done as a supplementary homework project. A total of 125 students participated to these activities and came from either a Chemical Engineering course (class 1, 
At the end of the activity, the teacher invited all students to evaluate the activities by completing a printed form containing ten questions with responses based on a Likert ${ }^{134}$ scale (the response rate was 95\%). Data are presented in Figure 3. In general, all statements showed high levels of agreement ("agree" and "strongly agree") on the benefits of pop culture, ranging from $60 \%$ to $92.8 \%$ of those surveyed.

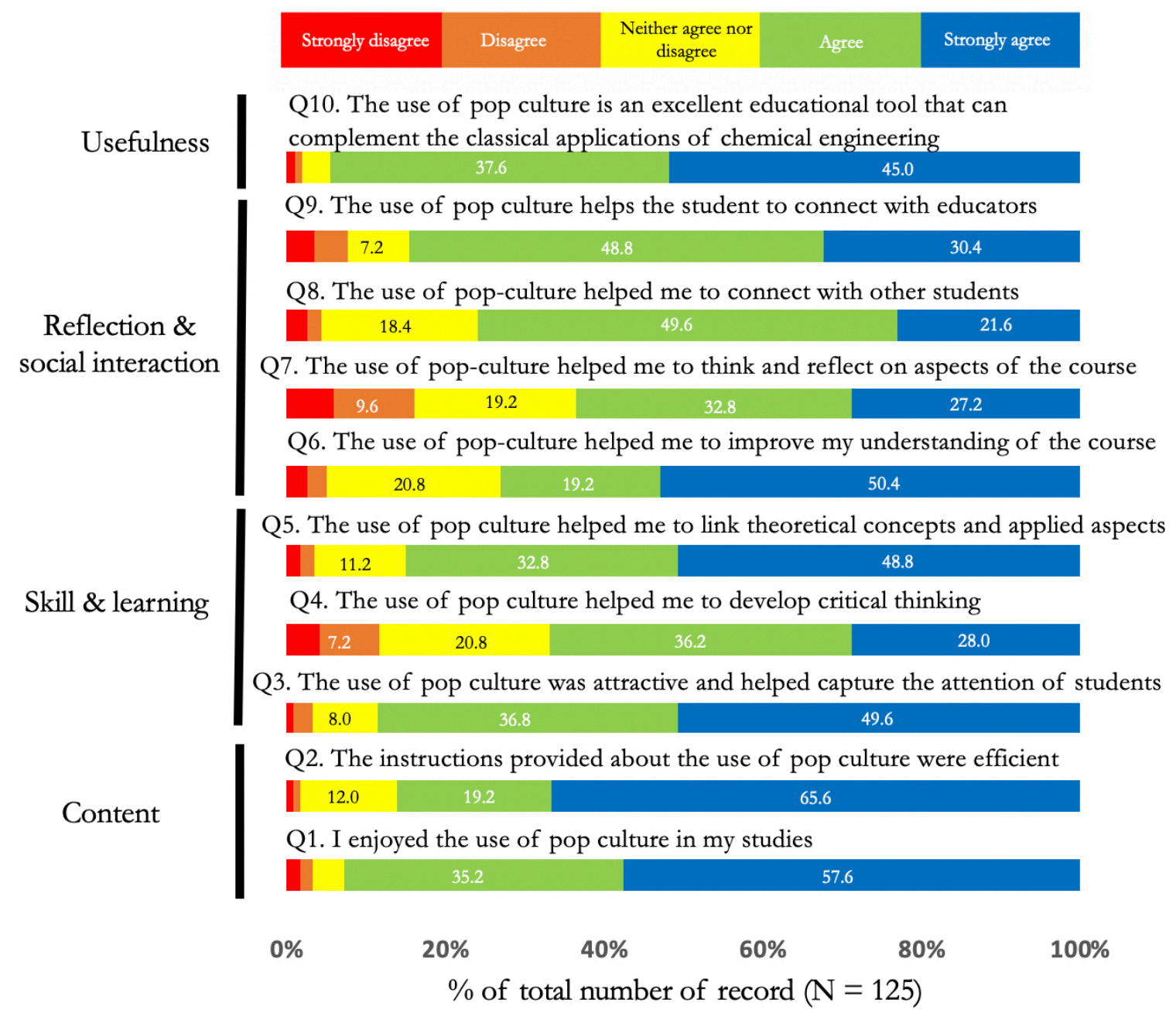

Figure 3. Student responses relating to the use of pop-culture in the courses. Total number of respondents $=125$ (academic year 2018/2019).

A majority of students (92.8\%) enjoyed the use of pop culture in the courses and 283 thought it was attractive and helped capture their attention (86.4\%). A majority (81.6\%) 284 also agreed that the use of pop culture elements helped them make connections between the 
theoretical aspects of the course and their application and helped improve their understanding (69.6\%). Fewer (64.8\%) students agreed that the pop culture helped them to develop their critical thinking or made them think about aspects of the course (60\%). It is worth noting that a majority thought that pop culture helped them to connect with other students $(71.2 \%)$ and even more with educators (79.2\%). Finally, a large majority $(83.2 \%)$ think that the use of pop culture is an excellent educational tool that can complement the classical application of chemical engineering. In a free-response section of the questionnaire, students were asked to provide comments on the activities. One of them was

"I will keep this exercise in mind all my life".

- SUGGESTIONS FOR ADDITIONAL OUTREACH ACTIVITIES

295

In this section, five supplementary activities based on recent pop-culture references are proposed as a support for educative purpose ("Spiderman", "Angry birds", "Stranger Things \& Chernobyl", "Raving rabbids" and "Dragon Ball"). All of them were performed with students' or visitors during open days or outreach forums. A specific evaluation is proposed at the end of this section to discuss the benefits of such activities.

302 As pointed out in the movie Into the Spider-Verse, Peter Parker has a degree in chemical 303 engineering and teaching materials can be developed from one of the most popular video games of 2018: Insomniac Games' Spider-Man. An important aspect of the game is 305 the completion of missions that involve collecting PAH (PolyAromatic Hydrocarbons) 306 samples, studying vehicle emissions, and determining the chemical composition of 307 atmospheric particulate matter ${ }^{135}$. The video game directly simulates chemical analysis 308 of these samples by having the player solve simplified versions of absorption spectra.

309 Completion of the collection and analysis of these samples grant the players research 310 tokens that can be used to upgrade their suit and gadgets. Though a limited amount of 311 the underlying scientific content is conveyed to the player in analyzing these spectra, it 312 is very straightforward to create a puzzle game using a similar format that could be an 
313 effective way to teach concepts in atomic spectroscopy. An example of such a puzzle 314 game is shown in Figure 4.a.

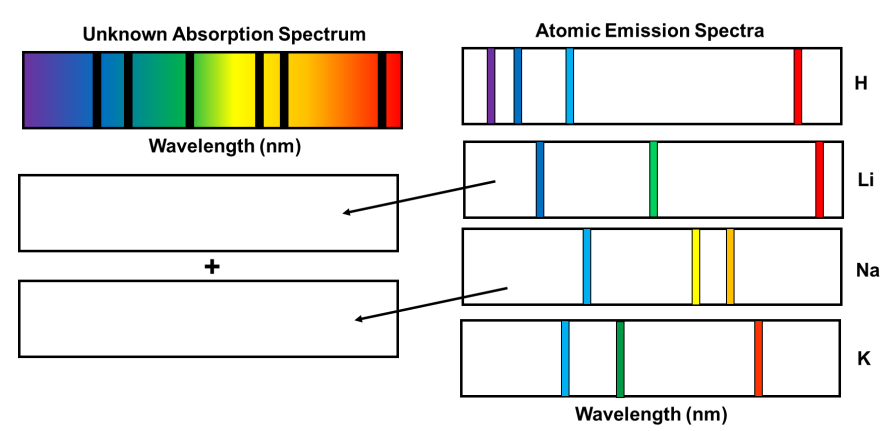

(a)

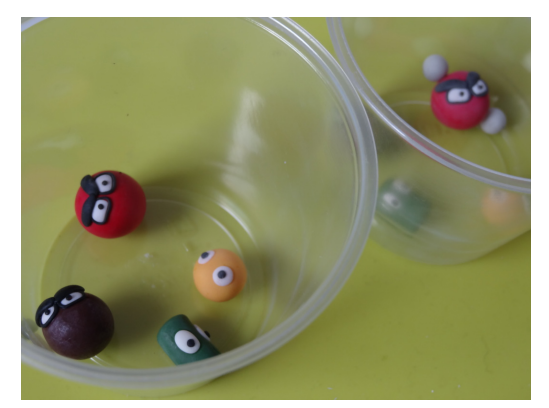

(b)

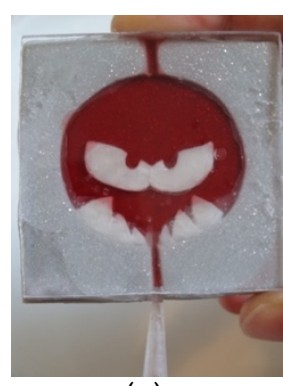

(c)

315 Figure 4. (a) Puzzle game to assign an unknown absorption spectrum using an inventory of atomic emission

316 spectra. (b) Particles made from modelling clay (FIMO ${ }^{\circledR}$ ) are used to mimic heterogeneous particles present in drinking water samples. Those with "angry" faces model waterborne pathogens that can be harmful to

318 humans and should be separated and detected to prevent outbreaks. (c) Macro-fluidic device made of

319 modelling clay, a Plexiglass layer and silicon for bonding ${ }^{\mathbf{1 3 6}}$.

320 In this puzzle, the player assigns the unknown absorption shown on the left as a

321 simple sum of the individual atomic spectra using the emission spectra inventory on

322 the right. Providing conceptual background about atomic absorption and emission

323 spectroscopy and using known line positions of hydrogen atom (Balmer Series) or alkali

324 atom spectra as shown in Figure 4.a conveys actual science to the player. In addition to 325 assigning spectra using a spectral line inventory, an exercise could be envisaged using

326 the Rydberg formula:

$$
\frac{1}{\lambda}=R Z^{2}\left(\frac{1}{n_{f}^{2}}-\frac{1}{n_{i}^{2}}\right)
$$

to predict the different electronic spectra by varying the nuclear charge and principal quantum numbers of hydrogenic atoms. ${ }^{137}$ The puzzle game could also be expanded to other kinds of absorption spectroscopy such as infrared (IR) absorption.

This activity is recommended for middle school students' and high school

332 students' as a game or a discussion in the classroom with a video of the game. This

333 inventory-based video game puzzle may be well-suited for an electron impact mass spectrometry-based game as well. Instead, consider that your fragment inventory

335 shown on the right is a molecular fragment inventory, and the player determines the 
336 molecular structure of the parent ion based on the fragmentation pattern. An

337 interactive, video game puzzle could also include variables like varying the electron

338 impact energies to show how the mass spectrum changes as a function of hard vs. soft 339 ionization.

340 ANGRY BIRDS

341 Another famous video game is Angry Birds, a casual puzzle video game developed by

342 Rovio Entertainment in 2009138. The gameplay revolves around players using a

343 slingshot to launch birds at pigs stationed in or around various structures, with the 344 goal of destroying all the pigs on the playing field. The Angry Birds series had a 345 combined tally of over 2 billion downloads across all platforms and has been adapted in 346 movies and television shows. In previous work, the franchise has been used as an 347 introduction to the separation of waterborne pathogens using microfluidics ${ }^{136}$, channels 348 in the micrometer range allowing for a precise control of fluid and particles at the 349 micrometer scale139. In this activity, the analogy with pop culture icons was used to 350 rapidly identify harmful pathogens in water samples. The wide range of particles that 351 would normally be present in water but not visible to the naked eye due to their 352 microscopic size are represented magnified using modelling clay. This activity is 353 recommended for middle school students' and high school students' as hands-on 354 activity. Some particles, representing pathogens that can cause a potential threat to 355 human health, have facial expressions mimicking those from the video game Angry 356 Birds for rapid identification (Figure 4.b). The overarching aim of the activity was then

357 to engineer a suite of devices that replicate ongoing research in the field to isolate those 358 "angry" pathogens and understand the chemistry associated with 1) the detection of 359 those pathogens (fluorescence), the manufacturing process (e.g. bonding) of microfluidic 360 devices (Figure 4.c) and how viscous liquids can be used to mimic at a macroscale a 361 microfluidic environment ${ }^{136,140}$.

364 Another TV shows that can be used for illustrating chemical reaction is Stranger Things, an American science fiction horror web television series created by the Duffer Brothers 
and released on Netflix in 2016. In the show a large tentacled monster named the Mind

367 Flayer terrorizes the citizens of Hawkins, and in season 3, it expresses a huge desire to consume chemicals, most often poisonous (e.g. fertilizer and cleaning products). The reason is that the monster wants to create caustic reactions associated with this chemical consumption to cause violent explosive transformations into amorphous blobs of human biomass. This example is a very good tool to discuss acid-base reactions and pH. Chernobyl is a historical drama television miniseries created and written by Craig Mazin and directed by Johan Renck for HBO in 2019. The series centers around the

374 Chernobyl nuclear disaster of April 1986 and the unprecedented cleanup efforts that followed. Chernobyl received widespread critical acclaim and became the highest rated TV show in history on some review platforms. The series is a very good example to discuss the operating principle of a nuclear power station, nuclear reactions and the

378 principle of radioactivity ${ }^{141}$. Other major accidents can also be mentioned (Three Mile 379 Island and Fukushima) in order to discuss the danger of this type of energy. Beyond the chemical aspect of the nuclear power plant, it is possible to encourage students to think about the series. For example, during episode 3, the basement of the plant is

382 successfully drained, but a nuclear meltdown has begun, threatening to contaminate 383 the groundwater. Authorities decide that a heat exchanger is needed under the plant to cool the reactor core and, according to the scientists, all the liquid nitrogen available in

385 the Soviet Union will be required. This can be solved from a chemical engineering point 386 of view, with a simple heat balance between the core of the plant and the nitrogen 387 flowing below the power station as described Equation (4):

$$
Q=m_{\text {core }} \cdot C_{p, \text { core }} \cdot \frac{d T}{d t}=U_{\text {heat exchanger }} . \text { Surface } \text { Heat Exhanger } . \Delta T_{m l}
$$

389 From this balance, the students can estimate, with some hypotheses on the parameters 390 of the reactor core given in the supplementary material, the amount of nitrogen 391 necessary to cool the power station down, from Equation 5:

$$
Q=W_{N_{2}} \cdot C_{p, N_{2}} \cdot\left(T_{N_{2}, \text { outlet }}-T_{N_{2}, \text { inlet }}\right)
$$


393 This show is thus a good example of the links between chemistry, chemical engineering,

394 reactor design and a recent pop-culture hit that could be used as project or a 395 discussion in the classroom for middle school students' and high school students'.

398 Rabbids Invasions is an animated television series that premiered in $2013^{142}$. The show 399 is based on the Raving Rabbids video game series produced by Ubisoft and created in $4002006{ }^{143}$. Among the hundreds of episodes of Rabbids invasions, developed by TeamTO 401 for Ubisoft Motion Pictures, some, e.g. episode 17 of season 1 ("Rabbid Dreams" by 402 Fabien Ouvrard \& Mélanie Duval, 2014), involve scientific observations of those strange creatures. Part of the action takes place in a lab comprising an experiment room 404 separated from a glass-walled observation office, where the scientists Gina and John try 405 to decipher the reaction of a sample rabbit. To make it more realistic, a library of 406 images has been compiled in which the cartoonist has selected the lab's etiquette. 407 Thus, along with the mandatory white lab coats, there is a board covered with scientific 408 formulas, some from physics and some from chemistry. The surprise is that the 409 chemistry ones are complex and related to a specific field of organic chemistry called 410 "photochromism" (reproduced in Figure 5a) and a chemical reaction describing the 411 light-induced coloration of a dye belonging to the spiropyran family is clearly visible ${ }^{144}$.

412 Photochromic dyes are commonly used in sunglasses, to adapt the optical density of the 413 lenses to the surrounding luminosity. However, spiropyran dyes are rather unstable 414 and fade away readily when used intensively. Thus, these dyes are now used for 415 pedagogical or research purposes. A famous example is the commercially available 416 "NitroBIPS", the photochemistry of which can be tested in the teaching lab"145,146. The 417 one on display in the Rabbid Invasion is the " $1^{\prime}, 3^{\prime}$-dihydro-8-methoxy-1', $3^{\prime}, 3^{\prime}$-trimethyl418 6-nitrospiro[2H-1-benzopyran-2,2'-(2H)-indole”, which differs from NitroBIPS by the 419 presence of an extra methoxy group $\mathrm{CH}_{3} \mathrm{O}$ on the ring carrying a nitro group $\mathrm{NO}_{2}$, and 420 is thus more expensive. As TeamTO is a French company, it is probably inspired from 421 work of the CEA-Paris that was working on such dyes ${ }^{147}$. The experiments could be 
done with students, using a polystyrene film and a UV light as depicted in Figure 5.b.

423 This activity is recommended for middle school students', high school students' or even 424 for open days as the reaction is fast and visual. Materials and methods for this activity 425 are detailed in the supplementary information.

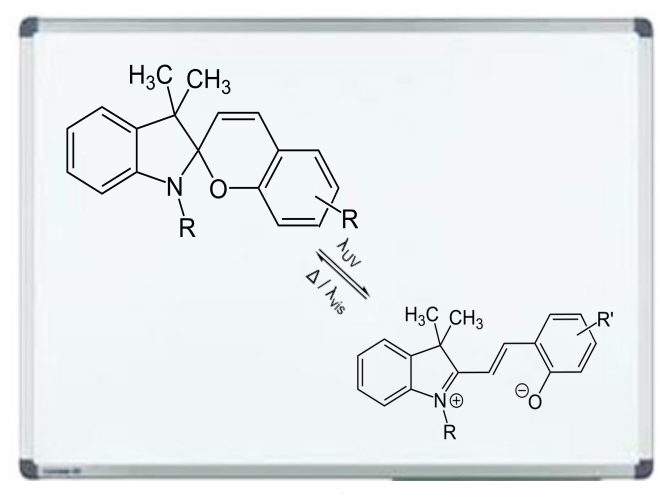

(a)

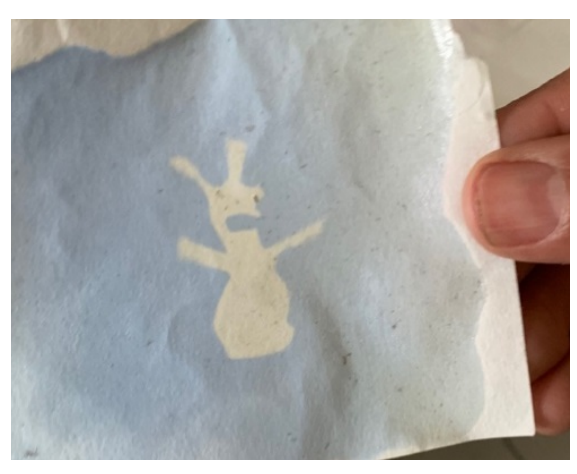

(b)
426

427

428

429

430

431

432

433

434

435

436

437

438

439

440

Figure 5. (a) Reproduction of the molecule presented in the Raving Rabbids (b) experiment to illustrate the photochromism of the NitroBIPS molecule with a Raving Rabbid as a blank marker.

\section{DRAGON BALL}

Dragon Ball is a Japanese manga franchise written and illustrated by Akira Toriyama originally serialized in Weekly Shōnen Jump magazine from 1984 to $1995^{148}$. Since its release, Dragon Ball has become one of the most successful manga and anime series of all time, having generated more than $\$ 20$ billion in total franchise revenue as of 2018 . Genki dama (元気玉) is one of the most powerful attacks of Son Goku, the famous hero of the anime (illustrated in Figure 6). It consists of a giant sphere of vital energy provided by all the living cells surrounding Goku. Although similarities seem to exist with the well-known Kamé Hamé Ha (かめかめ波), no real description of its energy nature can be found. While this energy is indeed able to vaporize in some of the anime episodes, this energy also appears as mostly mechanical in others (buildings destruction, etc). One reasonable hypothesis is to assume that it behaves as a blackbody, whose spectral irradiance distribution is given by the Planck distribution. This activity is recommended for middle high school or university students' (Chemical Engineering) as a project or a tutorial with professor. 
444 Thus, let us consider that this sphere is a blackbody of temperature $T_{G D}$, with a radius $445 r_{G D}=10 \mathrm{~m}$. Let also assume that the shortest distance between the sphere surface and 446 Son Goku is $p=20 \mathrm{~m}$ (see Figure 6). It is also important to note that no value for the 447 temperature $T_{G}$ seems available but, regarding the visible emission (bright blue) of the 448 Genki dama, a reasonable temperature would be around $6000 \mathrm{~K}$. The radiative 449 emission of Son Goku should also be neglected and Son Goku is assumed to be a 450 cylinder of height $l_{2}-l_{1}-r_{G D}=1.8 \mathrm{~m}$ and radius $r_{S G}=0.3 \mathrm{~m}$. In order to propose an 451 original work to the student, we propose to calculate the net radiative flux from the 452 Genki dama to Son Goku.

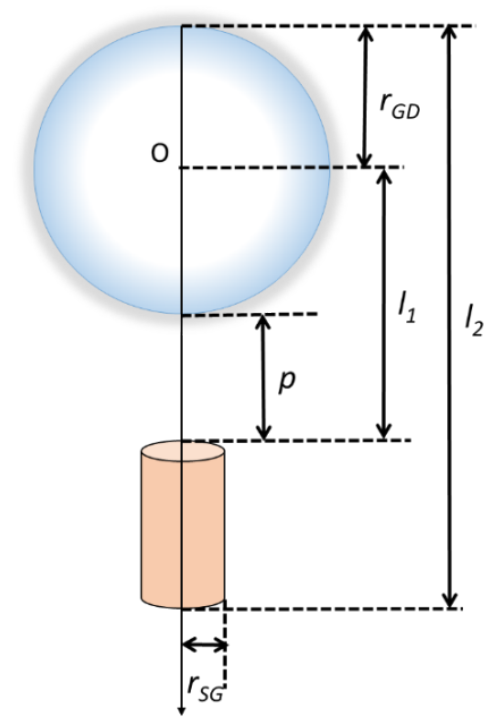

453

454

455

456

457

458

459

460

461 462

Figure 6. Scheme of the problem

The net radiative flux between two blackbodies is given by the Stefan-Boltzmann radiation law, assuming that both material emissivities are close to 1 :

$$
q_{G D-S G}=q_{G D \rightarrow S G}-q_{S G \rightarrow G D} \simeq A_{G D} F_{G D-S G} \sigma T_{G D}^{4}
$$

With $A_{G D}\left(\mathrm{~m}^{2}\right)$ the total area of the Genki dama, $F_{G D-S G}$ the view factor from the GenkiDama sphere to Son Goku, assumed as the external surface of a coaxial cylinder (see Figure 6). $\sigma=5.67 \times 10^{-8} \mathrm{~W} /\left(\mathrm{m}^{2} \mathrm{~K}^{4}\right)$ is the Stefan-Boltzmann constant. The resolution of the problem is given in the supplementary section. 
463 As some of these suggested additional activities were not tested in situ with students,

464 they were presented to a panel of students' $(\mathrm{N}=35$ - Chemistry, Environment and 465 Chemical Engineering - Academic year 2019/2020) during a scientific discussion (2 h) 466 on the links between science and pop-culture in order to evaluate students'. The survey 467 was conducted as an anonymous paper exercise, with students required to strongly 468 agree, agree, neither/neutral, disagree or strongly disagree with a series of 10 469 statements. The majority of respondents were positive about educational benefits of pop 470 culture with $82 \%$ of the respondents agreeing that the use of pop culture was a useful 471 learning activity. More specifically, $75 \%$ of the students agreed (or strongly agreed) that 472 pop culture had helped them apply chemistry/chemical engineering in a useful way. 473 Having just discussed about these pop-culture activities, the majority of respondents 474 agreed (78\%) that they would appreciate this approach in different subject areas of their 475 cursus. These findings support the high level of student engagement and interaction 476 observed by instructors when pop-culture is used. The data collected show that the 477 majority of students enjoyed discussing science with a pop culture approach, in the 478 open section of the survey some students' recommended to use it at a recreative 479 moment between students' or with educators.

481 Pop-culture in classrooms can be beneficial as it creates engaging links between 482 chemical concepts and their applications, and between educators' and students' 483 interests. The objective is not to promote movies or video games but to connect and use 484 the interest of students for these pop culture elements towards learning science. 485 Connection with recent pop culture elements such as those proposed in the present 486 work could be used as support for demonstrating reactions, as side projects, analogies 487 to communicate concepts and/or as a platform to start discussions. Educators need to 488 be careful about inappropriate content depending on the student's age, to avoid spoiling anything for someone reading or watching a show, movie or book, to make sure the science involved is actually correct. It is also important to leave the students free to 
search chemistry during project in all types of media, recent or not, according to their

492 interests to unleash their curiosity. Finally, pop-culture promotes critical thinking and

493 cultural literacy, which are important skills for students to develop.

\section{CONCLUSION}

495 The present work provides creative and original activities based on pop culture (e.g. 496 video games, movies and TV series) to engage chemistry and chemical engineering 497 students. The goal has been to show that chemistry and chemical engineering 498 phenomena are widely present and play an essential role in recent pop culture as 499 typified in the superhero movies, action video games or fantasy drama series. 500 Instructors can stimulate students' interest in these domains by discussing the 501 chemical content of such works during lectures, tutorials, by generating quizzes and assignment items based on occurrences in these videogames and movies, or by creating

503 a stock of scientific trivia collected from popular culture sources. To conclude, pop504 culture offers a wide range of possibilities for involving students in classroom, from 505 hands-on activity to critical thinking, and from basic chemistry to chemical engineering.

\section{ASSOCIATED CONTENT}

507 Supporting Information

508 Fortnite: Making "slurp juice"; Game of Thrones and Harry Potter: Making green fire;

509 Breaking Bad: Synthesizing dexerine; The Black Panther movie: Proposing a process flow

510 diagram for fabrication of "vibranium steel"; Raving Rabbids: Making color-changing paper;

511 Dragon Ball: Calculating the net radiative flux from the Genki Dama to Son Goku (DOCX)

\section{AUTHOR INFORMATION}

513 Nicolas DIETRICH

514 E-mail: nicolas.dietrich@insa-toulouse.fr

515 Personal website: ndietrich.com

516 ORCID: orcid.org/0000-0001-6169-3101

517 Mélanie JIMENEZ

518 E-mail: Melanie.Jimenez@glasgow.ac.uk

519 Personal website: https://jimenezmelanie.weebly.com

520 Researcher ID: D-8469-2016/ORCID number: 0000-0002-4631-0608

521 Manuel SOUTO

522 E-mail: Manuel.Souto@ua.pt

523 Personal website: https://ciceco.ua.pt/manuelsouto

524 Researcher ID: D-1014-2017/ORCID number: 0000-0003-3491-6984

525 Aaron W. HARRISON

526 E-mail: aharrison@chapman.edu

527 ORCID: orcid.org/0000-0003-3102-8201

528 Christophe COUDRET 
E-mail: coudret@,chimie.ups-tlse.fr

ORCID number: 0000-0001-7334-5112

Note: The authors declare no competing financial interest.

534 (1) Skluzacek, J. M.; Harper, J.; Herron, E.; Bortiatynski, J. M. Summer Camp To Engage Students in Nutritional Chemistry Using Popular Culture and Hands-On Activities. J. Chem. Educ. 2010, 87 (5), 492-495. https://doi.org/10.1021/ed8001732.

(2) Clapson, M. L.; Gilbert, B.; Mozol, V. J.; Schechtel, S.; Tran, J.; White, S. ChemEscape: Educational Battle Box Puzzle Activities for Engaging Outreach and Active Learning in General Chemistry. J. Chem. Educ. 2020, 97 (1), 125-131. https://doi.org/10.1021/acs.jchemed.9b00612.

541 (3) Clauss, A. W. Using Popular Culture To Teach Chemistry. J. Chem. Educ. 2009, 86 (10), 1223. https://doi.org/10.1021/ed086p1223.

(4) Pye, C. C. Chemistry and Song: A Novel Way To Educate and Entertain. J. Chem. Educ. 2004, 81 (4), 507. https://doi.org/10.1021/ed081p507.

(5) Last, A. M. Combining Chemistry and Music To Engage Students' Interest. Using Songs To Accompany Selected Chemical Topics. J. Chem. Educ. 2009, 86 (10), 1202. https://doi.org/10.1021/ed086p1202.

548 (6) Behrman, E. J. Music and Chemistry. J. Chem. Educ. 2005, 82 (1), 37.

549 https://doi.org/10.1021/ed082p37.1.

$550 \quad$ (7) Ward, S. J.; Price, R. M.; Davis, K.; Crowther, G. J. Songwriting to Learn: How High School Science Fair Participants Use Music to Communicate Personally Relevant Scientific Concepts. International Journal of Science Education, Part B 2018, 8 (4), 307-324. https://doi.org/10.1080/21548455.2018.1492758.

(8) Crowther, G. J.; Davis, K. Amino Acid Jazz: Amplifying Biochemistry Concepts with Content-Rich Music. J. Chem. Educ. 2013, 90 (11), 1479-1483. https://doi.org/10.1021/ed400006h.

(9) André, J. P. Opera and Poison: A Secret and Enjoyable Approach To Teaching and Learning Chemistry. J. Chem. Educ. 2013, 90 (3), 352-357. https://doi.org/10.1021/ed300445b.

(10) Cobb, C. The Chemistry of Lucrezia Borgia et al. In Characters in Chemistry: A Celebration of the Humanity of Chemistry; American Chemical Society: Washington, DC, 2013; Chapter 5, pp 61-72; DOI: 10.1021/bk-2013-1136.ch005

(11) Uffelman, E. S. Teaching Science in Art: Technical Examination of 17th-Century Dutch Painting as Interdisciplinary Coursework for Science Majors and Nonmajors. Journal of Chemical Education 2007, 84 (10), 1617-1624.

(12) Nivens, D. A.; Padgett, C. W.; Chase, J. M.; Verges, K. J.; Jamieson, D. S. Art, Meet Chemistry; Chemistry, Meet Art: Case Studies, Current Literature, and Instrumental Methods Combined To Create a Hands-On Experience for Nonmajors and Instrumental Analysis Students. J. Chem. Educ. 2010, 87 (10), 1089-1093. https://doi.org/10.1021/ed100352f. (13) Burke, S. N.; Farling, C. G.; Svoboda, S. A.; Wustholz, K. L. Research with Undergraduates at the Intersection of Chemistry and Art: Surface-Enhanced Raman Scattering Studies of Oil Paintings. In Raman Spectroscopy in the Undergraduate Curriculum; ACS Symposium Series; American Chemical Society, 2018; Vol. 1305, pp 165-180. https://doi.org/10.1021/bk-2018-1305.ch010.

(14) Tallman, K. A. Introducing Students to Fundamental Chemistry Concepts and Basic Research through a Chemistry of Fashion Course for Nonscience Majors. J. Chem. Educ. J. Chem. Educ. 2019, 96 (9), 1906-1913; DOI: 10.1021/acs.jchemed.8b00826

578 (15) Samet, C.; Higgins, P. J. Napoleon's Buttons: Teaching the Role of Chemistry in 
History. J. Chem. Educ. 2005, 82 (10), 1496. https://doi.org/10.1021/ed082p1496.

580 (16) Bucholtz, K. M. Spicing Things Up by Adding Color and Relieving Pain: The Use of

581 Napoleon's Buttons in Organic Chemistry. J. Chem. Educ. 2011, 88 (2), 158-161.

582 https://doi.org/10.1021/ed100374w.

583 (17) Bucholtz, K. M. Historical Examples Integrated into the Organic Chemistry

584

585

Curriculum. In Advances in Teaching Organic Chemistry; ACS Symposium Series; American Chemical Society, 2012; Vol. 1108, pp 131-150. https://doi.org/10.1021/bk-2012-

586 1108.ch009.

587

588

(18) Federico, E. D.; Kehlet, C.; Schahbaz, H.; Charton, B. ConfChem Conference on

Case-Based Studies in Chemical Education: Chemistry of Pompeii and Herculaneum-A

589

Case Study Course in Chemistry at the Interface of Ancient Technology and Archeological

590 Conservation. J. Chem. Educ. 2013, 90 (2), 264-265. https://doi.org/10.1021/ed200801s.

591

592

593

594

595

596

597

598

599

(19) Beilby, A. L. Art, Archaeology, and Analytical Chemistry: A Synthesis of the Liberal Arts. J. Chem. Educ. 1992, 69 (6), 437. https://doi.org/10.1021/ed069p437.

(20) Giménez, J. Finding Hidden Chemistry in Ancient Egyptian Artifacts: Pigment Degradation Taught in a Chemical Engineering Course. J. Chem. Educ. 2015, 92 (3), 456462. https://doi.org/10.1021/ed500327j.

(21) Harper, C. S.; Macdonald, F. V.; Braun, K. L. Lipid Residue Analysis of Archaeological Pottery: An Introductory Laboratory Experiment in Archaeological Chemistry. J. Chem. Educ. 2017, 94 (9), 1309-1313.

https://doi.org/10.1021/acs.jchemed.7b00225.

600 (22) Labianca, D. A.; Reeves, W. J. An Interdisciplinary Approach to Science and 601 Literature. J. Chem. Educ. 1975, 52 (1), 66. https://doi.org/10.1021/ed052p66.

602 (23) Liberko, C. A. Using Science Fiction To Teach Thermodynamics: Vonnegut, Ice-

603 Nine, and Global Warming. J. Chem. Educ. 2004, 81 (4), 509.

604 https://doi.org/10.1021/ed081p509.

605 (24) Schwartz, A. T. Chemistry Education, Science Literacy, and the Liberal Arts. 2007

606 George C. Pimentel Award. J. Chem. Educ. 2007, 84 (11), 1750.

607 https://doi.org/10.1021/ed084p1750.

608 (25) Spillane, N. K. What's Copenhagen Got To Do With Chemistry Class? Using a Play 609 to Teach the History and Practice of Science. J. Chem. Educ. 2013, 90 (2), 219-223.

610 https://doi.org/10.1021/ed2007058.

611 (26) Herrick, R. S.; Cording, R. K. Using a Poetry Reading on Hemoglobin To Enhance

612 Subject Matter. J. Chem. Educ. 2013, 90 (2), 215-218. https://doi.org/10.1021/ed300129q.

613 (27) Afonso, A. S.; Gilbert, J. K. The Role of 'Popular' Books in Informal Chemical

614 Education. International Journal of Science Education, Part B 2013, 3 (1), 77-99.

615 https://doi.org/10.1080/21548455.2012.733439.

616 (28) Kloepper, K. D. Bringing in the Bard: Shakespearean Plays as Context for

617

618

619

620 Science Helps Solve a Classic Crime. J. Chem. Educ. 2012, 89 (5), 629-635. Instrumental Analysis Projects. J. Chem. Educ. 2015, 92 (1), 79-85. https://doi.org/10.1021/ed500504r.

621 https://doi.org/10.1021/ed200289t.

622 (30) Last, A. M. Chemistry in Victorian Detective Fiction: "A Race with the Sun." J.

623 Chem. Educ. 2012, 89 (5), 636-639. https://doi.org/10.1021/ed200110z.

624 (31) Last, A. M. Chemistry and Popular Culture: The 007 Bond. J. Chem. Educ. 1992, 69

625 (3), 206. https://doi.org/10.1021/ed069p206.

626 (32) Copes, J. S. The Chemical Wizardry of J. K. Rowling. J. Chem. Educ. 2006, 83 (10), 1479. https://doi.org/10.1021/ed083p1479.

(33) Waddell, T. G.; Rybolt, T. R. The Chemical Adventures of Sherlock Holmes: The Case of the Screaming Stepfather. J. Chem. Educ. 1992, 69 (12), 999. 
631 (34) Waddell, T. G.; Rybolt, T. R. The Chemical Adventures of Sherlock Holmes: The Blackwater Escape. J. Chem. Educ. 2003, 80 (4), 401. https://doi.org/10.1021/ed080p401. (35) Shaw, K. The Chemical Adventures of Sherlock Holmes: The Serpentine Remains. J. Chem. Educ. 2008, 85 (4), 507. https://doi.org/10.1021/ed085p507.

(36) Southward, R. E.; Hollis, W. G.; Thompson, D. W. Precipitation of a Murder: A Creative Use of Strychnine Chemistry in Agatha Christie's The Mysterious Affair at Styles. $J$. Chem. Educ. 1992, 69 (7), 536. https://doi.org/10.1021/ed069p536.

(37) Hollis, W. G. Jurassic Park as a Teaching Tool in the Chemistry Classroom. J. Chem. Educ. 1996, 73 (1), 61. https://doi.org/10.1021/ed073p61.

(38) Kennepohl, D.; Roesky, H. W. Drawing Attention with Chemistry Cartoons. J. Chem. Educ. 2008, 85 (10), 1355. https://doi.org/10.1021/ed085p1355.

(39) Giese, R. W. Connecting Current Literature, Cartoons, and Creativity: Incorporating Student-Created Cartoons in a Biochemistry Course to Enhance Learning. J. Chem. Educ. 2020, 97 (2), 462-465; DOI: 10.1021/acs.jchemed.9b00876.

(40) Kakalios, J. The Materials Science of Marvel's The Avengers-Some Assembly Required. In Hollywood Chemistry; ACS Symposium Series; American Chemical Society, 2013; Vol. 1139, pp 215-227. https://doi.org/10.1021/bk-2013-1139.ch018.

(41) Szafran, Z.; Pike, R. M.; Singh, M. M. Microscale Chemistry in the Comics. J. Chem. Educ. 1994, 71 (6), A151. https://doi.org/10.1021/ed071pA151.

(42) Carter, H. A. Chemistry in the Comics: Part 1. A Survey of the Comic Book Literature. J. Chem. Educ. 1988, 65 (12), 1029. https://doi.org/10.1021/ed065p1029.

(43) Carter, H. A. Chemistry in the Comics: Part 2. Classic Chemistry. J. Chem. Educ. 1989, 66 (2), 118. https://doi.org/10.1021/ed066p118.

(44) Carter, H. A. Chemistry in the Comics: Part 3. The Acidity of Paper. J. Chem. Educ. 1989, 66 (11), 883. https://doi.org/10.1021/ed066p883.

(45) Carter, H. A. Chemistry in the Comics: Part 4. The Preservation and Deacidification of Comic Books. J. Chem. Educ. 1990, 67 (1), 3. https://doi.org/10.1021/ed067p3.

(46) Ruekberg, B. A Chemistry Tidbit for Batman Fans. J. Chem. Educ. 2010, 87 (10), 1017-1018. https://doi.org/10.1021/ed1003228.

(47) Di Raddo, P. Teaching Chemistry Lab Safety through Comics. J. Chem. Educ. 2006, 83 (4), 571. https://doi.org/10.1021/ed083p571.

(48) Kumasaki, M.; Shoji, T.; Wu, T.-C.; Soontarapa, K.; Arai, M.; Mizutani, T.; Okada, K.; Shimizu, Y.; Sugano, Y. Presenting Safety Topics Using a Graphic Novel, Manga, To Effectively Teach Chemical Safety to Students in Japan, Taiwan, and Thailand. J. Chem. Educ. 2018, 95 (4), 584-592. https://doi.org/10.1021/acs.jchemed.7b00451.

(49) Frey, C. A.; Mikasen, M. L.; Griep, M. A. Put Some Movie Wow! In Your Chemistry Teaching. J. Chem. Educ. 2012, 89 (9), 1138-1143. https://doi.org/10.1021/ed300092t. (50) Baños i Díez, J. E.; Bosch Llonch, F. Using Feature Films as a Teaching Tool in Medical Schools. Educación Médica. 2015, 6(4), 206-11. http://dx.doi.org/10.1016/j.edumed.2015.09.001.

(51) Goll, J. G.; Woods, B. J. Teaching Chemistry Using the Movie Apollo 13. J. Chem. Educ. 1999, 76 (4), 506. https://doi.org/10.1021/ed076p506.

(52) Goll, J. G.; Wilkinson, L. J.; Snell, D. M. Teaching Chemistry Using October Sky. J. Chem. Educ. 2009, 86 (2), 177. https://doi.org/10.1021/ed086p177.

(53) Bormanis, A. Science Fictions and Fictional Science: A Brief Tour of Science in the Star Trek Universe. In Hollywood Chemistry; ACS Symposium Series; American Chemical Society, 2013; Vol. 1139, pp 17-24. https://doi.org/10.1021/bk-2013-1139.ch002.

(54) Wink, D. J. "Almost Like Weighing Someone's Soul": Chemistry in Contemporary Film. J. Chem. Educ. 2001, 78 (4), 481. https://doi.org/10.1021/ed078p481.

680 (55) Griep, M. A.; Mikasen, M. L. Based on a True Story: Using Movies as Source 
682 https://doi.org/10.1021/ed082p1501.

683 (56) Taarea, D.; Thomas, N. C. The Elements Go to the Movies. J. Chem. Educ. 2010, 87

684

685

686

687

688

689

690 (10), 1056-1059. https://doi.org/10.1021/ed1002543.

(57) Stengler, E. Beyond Teaching and Learning: Bringing Together Science and Society with and through Movies. In Hollywood Chemistry; ACS Symposium Series; American Chemical Society, 2013; Vol. 1139, pp 289-297. https://doi.org/10.1021/bk-20131139.ch024.

691 (59) Collins, S. N.; Appleby, L. Black Panther, Vibranium, and the Periodic Table. J.

692 Chem. Educ. 2018, 95 (7), 1243-1244. https://doi.org/10.1021/acs.jchemed.8b00206.

693 (60) King, D. The Science (and the Scientists) Behind 'Ant-Man' - The New York Times.

6942018.

695 (61) Allain, R. The Physics of Spider-Man's Webs. Wired. April 29, 2014.

696 (62) Slabaugh, W. H. Trends in Instruction of Chemistry by Films and Television. J. Chem.

697 Educ. 1959, 36 (12), 588. https://doi.org/10.1021/ed036p588.

698 (63) Clark, T. M.; Cervenec, J.; Mamais, J. "The Price Is Right” for Your Classroom. J.

699 Chem. Educ. 2011, 88 (4), 428-431. https://doi.org/10.1021/ed100224w.

700 (64) Li, R.; Orthia, L. A. Communicating the Nature of Science Through The Big Bang

701 Theory: Evidence from a Focus Group Study. International Journal of Science Education,

702 Part B 2016, 6 (2), 115-136. https://doi.org/10.1080/21548455.2015.1020906.

703 (65) Cass, S.; Grazier, K. R.; Thompson, B.; Marrinan, C. Constructing Crimes: How the

704 CSI Effect Is Created. In Hollywood Chemistry; ACS Symposium Series; American Chemical Society, 2013; Vol. 1139, pp 145-151. https://doi.org/10.1021/bk-2013-1139.ch012.

(66) Orthia, L. A.; Dobos, A. R.; Guy, T.; Kan, S. Z.; Keys, S. E.; Nekvapil, S.; Ngu, D. H. Y. How Do People Think About the Science They Encounter in Fiction? Undergraduates Investigate Responses to Science in The Simpsons. International Journal of Science Education, Part B 2012, 2 (2), 149-174. https://doi.org/10.1080/21548455.2011.610134. (67) Milanick, M. A.; Prewitt, R. L. Fact or Fiction? General Chemistry Helps Students Determine the Legitimacy of Television Program Situations. J. Chem. Educ. 2013, 90 (7), 904-906. https://doi.org/10.1021/ed300155p.

713 (68) Millard, J. T. Television Medical Dramas as Case Studies in Biochemistry. J. Chem.

714 Educ. 2009, 86 (10), 1216. https://doi.org/10.1021/ed086p1216.

715 (69) Costa, M. J. CARBOHYDECK: A Card Game To Teach the Stereochemistry of 716 Carbohydrates. J. Chem. Educ. 2007, 84 (6), 977. https://doi.org/10.1021/ed084p977.

717 (70) Nowosielski, D. A. Use of a Concentration Game for Environmental Chemistry Class Review. J. Chem. Educ. 2007, 84 (2), 239. https://doi.org/10.1021/ed084p239.

(71) Roštejnská, M.; Klímová, H. Biochemistry Games: AZ-Quiz and Jeopardy! J. Chem. Educ. 2011, 88 (4), 432-433. https://doi.org/10.1021/ed100231r.

(72) Domínguez, A.; Saenz-de-Navarrete, J.; de-Marcos, L.; Fernández-Sanz, L.; Pagés, C.; Martínez-Herráiz, J.-J. Gamifying Learning Experiences: Practical Implications and Outcomes. Computers \& Education 2013, 63, 380-392.

https://doi.org/10.1016/j.compedu.2012.12.020.

725 (73) Silva, D. de M.; Ribeiro, C. M. R. Analogue Three-Dimensional Memory Game for 726 Teaching Reflection, Symmetry, and Chirality to High School Students. J. Chem. Educ. 2017. 727 https://doi.org/10.1021/acs.jchemed.7b00219.

728 (74) Triboni, E.; Weber, G. MOL: Developing a European-Style Board Game To Teach 729 Organic Chemistry. J. Chem. Educ. 2018, 95 (5), 791-803.

730 https://doi.org/10.1021/acs.jchemed.7b00408.

731 (75) Adair, B. M.; McAfee, L. V. Chemical Pursuit: A Modified Trivia Board Game. J. 
Chem. Educ. 2018, 95 (3), 416-418. https://doi.org/10.1021/acs.jchemed.6b00946.

(76) da Silva Júnior, J. N.; Santos de Lima, P. R.; Sousa Lima, M. A.; Monteiro, Á. C.; Silva de Sousa, U.; Melo Leite Júnior, A. J.; Vega, K. B.; Alexandre, F. S. O.; Monteiro, A. J. Time Bomb Game: Design, Implementation, and Evaluation of a Fun and Challenging Game Reviewing the Structural Theory of Organic Compounds. J. Chem. Educ. 2020, 97 (2), 565570; DOI: 10.1021/acs.jchemed.9b00571

(77) Iribe, J.; Hamada, T.; Kim, H.; Voegtle, M.; Bauer, C. A. Rolling the Dice: Modeling First- and Second-Order Reactions via Collision Theory Simulations in an Undergraduate Laboratory. J. Chem. Educ. 2020, 97 (3), 764-771. https://doi.org/10.1021/acs.jchemed.9b00657.

(78) Yayon, M.; Rap, S.; Adler, V.; Haimovich, I.; Levy, H.; Blonder, R. Do-It-Yourself: Creating and Implementing a Periodic Table of the Elements Chemical Escape Room. $J$. Chem. Educ. 2020, 97 (1), 132-136. https://doi.org/10.1021/acs.jchemed.9b00660. (79) da Silva Júnior, J. N.; Sousa Lima, M. A.; Silva de Sousa, U.; do Nascimento, D. M.; Melo Leite Junior, A. J.; Vega, K. B.; Roy, B.; Winum, J.-Y. Reactions: An Innovative and Fun Hybrid Game to Engage the Students Reviewing Organic Reactions in the Classroom. $J$. Chem. Educ. 2020, 97, 3, 749-753. https://doi.org/10.1021/acs.jchemed.9b01020.

(80) da Silva Júnior, J. N.; Uchoa, D. E. de A.; Sousa Lima, M. A.; Monteiro, A. J. Stereochemistry Game: Creating and Playing a Fun Board Game To Engage Students in Reviewing Stereochemistry Concepts. J. Chem. Educ. 2019, 96 (8), 1680-1685. https://doi.org/10.1021/acs.jchemed.8b00897. (81) Sousa Lima, M. A.; Monteiro, Á. C.; Melo Leite Junior, A. J.; de Andrade Matos, I. S.; Alexandre, F. S. O.; Nobre, D. J.; Monteiro, A. J.; da Silva Júnior, J. N. Game-Based Application for Helping Students Review Chemical Nomenclature in a Fun Way. J. Chem. Educ. 2019, 96 (4), 801-805. https://doi.org/10.1021/acs.jchemed.8b00540.

(82) da Silva Júnior, J. N.; Sousa Lima, M. A.; Nunes Miranda, F.; Melo Leite Junior, A. J.; Alexandre, F. S. O.; de Oliveira Assis, D. C.; Nobre, D. J. Nomenclature Bets: An Innovative Computer-Based Game To Aid Students in the Study of Nomenclature of Organic Compounds. J. Chem. Educ. 2018, 95 (11), 2055-2058. https://doi.org/10.1021/acs.jchemed.8b00298.

(83) Dietrich, N. Chem and Roll: A Roll and Write Game To Illustrate Chemical Engineering and the Contact Process. J. Chem. Educ. 2019, 96 (6), 1194-1198. https://doi.org/10.1021/acs.jchemed.8b00742.

(84) Battersby, G. L.; Beeley, C.; Baguley, D. A.; Barker, H. D.; Broad, H. D.; Carey, N. C.; Chambers, E. S.; Chodaczek, D.; Blackburn, R. A. R.; Williams, D. P. Go Fischer: An Introductory Organic Chemistry Card Game. J. Chem. Educ. 2020, 97 (8), 2226-2230. https://doi.org/10.1021/acs.jchemed.0c00504.

(85) Estudante, A.; Dietrich, N. Using Augmented Reality to Stimulate Students and Diffuse Escape Game Activities to Larger Audiences. J. Chem. Educ. 2020, 97 (5), 13681374. https://doi.org/10.1021/acs.jchemed.9b00933.

(86) Monnot, M.; Laborie, S.; Hébrard, G.; Dietrich, N. New Approaches to Adapt Escape Game Activities to Large Audience in Chemical Engineering: Numeric Supports and Students' Participation. Education for Chemical Engineers 2020, 32, 50-58. https://doi.org/10.1016/j.ece.2020.05.007.

(87) Brassinne, K.; Reynders, M.; Coninx, K.; Guedens, W. Developing and Implementing GAPc, a Gamification Project in Chemistry, toward a Remote Active Student-Centered Chemistry Course Bridging the Gap between Precollege and Undergraduate Education. $J$. Chem. Educ. 2020, 97(8), 2147-2152. https://doi.org/10.1021/acs.jchemed.9b00986.

(88) Vergne, M. J.; Simmons, J. D.; Bowen, R. S. Escape the Lab: An Interactive EscapeRoom Game as a Laboratory Experiment. J. Chem. Educ. 2019, 96 (5), 985-991. https://doi.org/10.1021/acs.jchemed.8b01023. 
(89) Vergne, M. J.; Smith, J. D.; Bowen, R. S. Escape the (Remote) Classroom: An Online Escape Room for Remote Learning. J. Chem. Educ. 2020, 97 (9), 2845-2848. https://doi.org/10.1021/acs.jchemed.0c00449. (90) Dietrich, N.; Wongwailikhit, K.; Mei, M.; Xu, F.; Felis, F.; Kherbeche, A.; Hébrard, G.; Loubière, K. Using the "Red Bottle" Experiment for the Visualization and the Fast Characterization of Gas-Liquid Mass Transfer. J. Chem. Educ. 2019, 96 (5), 979-984. https://doi.org/10.1021/acs.jchemed.8b00898. Investigate the Enhancement Factor of an Oxygen-Sensitive Colorimetric Reaction Using Microreactors. AIChE Journal 2017, 63 (6), 2272-2284. (92) Yang, L.; Loubière, K.; Dietrich, N.; Le Men, C.; Gourdon, C.; Hébrard, G. Local Investigations on the Gas-Liquid Mass Transfer around Taylor Bubbles Flowing in a Meandering Millimetric Square Channel. Chemical Engineering Science 2017, 165, 192-203. https://doi.org/10.1016/j.ces.2017.03.007.

(93) Dietrich, N.; Mayoufi, N.; Poncin, S.; Midoux, N.; Li, H. Z. Bubble Formation at an Orifice: A Multiscale Investigation. Chem. Eng. Sci. 2013, 92, 118-125.

https://doi.org/10.1016/j.ces.2012.12.033.

(94) Dietrich, N.; Francois, J.; Jimenez, M.; Cockx, A.; Guiraud, P.; Hébrard, G. Fast Measurements of the Gas-Liquid Diffusion Coefficient in the Gaussian Wake of a Spherical Bubble. Chem. Eng. Technol. 2015, 38 (5), 941-946. https://doi.org/10.1002/ceat.201400471. (95) Xu, F.; Hébrard, G.; Dietrich, N. Comparison of Three Different Techniques for GasLiquid Mass Transfer Visualization. International Journal of Heat and Mass Transfer 2020, 150, 119261. https://doi.org/10.1016/j.ijheatmasstransfer.2019.119261.

(96) Xu, F.; Midoux, N.; Li, H.-Z.; Hébrard, G.; Dietrich, N. Characterization of Bubble Shapes in Non-Newtonian Fluids by Parametric Equations. Chemical Engineering \& Technology 2019, 42 (11), 2321-2330. https://doi.org/10.1002/ceat.201800690.

(97) Xu, F.; Cockx, A.; Hébrard, G.; Dietrich, N. Mass Transfer and Diffusion of a Single Bubble Rising in Polymer Solutions. Ind. Eng. Chem. Res. 2018, 57 (44), 15181-15194. https://doi.org/10.1021/acs.iecr.8b03617.

(98) Dietrich, N. Escape Classroom: The Leblanc Process-An Educational "Escape Game." J. Chem. Educ. 2018, 95 (6), 996-999. https://doi.org/10.1021/acs.jchemed.7b00690. (99) Burks, R.; Deards, K. D.; DeFrain, E. Where Science Intersects Pop Culture: An Informal Science Education Outreach Program. J. Chem. Educ. 2017, 94 (12), 1918-1924. https://doi.org/10.1021/acs.jchemed.7b00070. (100) The Video Games' Industry is Bigger Than Hollywood http://lpesports.com/e-sportsnews/the-video-games-industry-is-bigger-than-hollywood (accessed Jul 28, 2019).

(101) Video game https://en.wikipedia.org/w/index.php?title=Video_game\&oldid=908034167 (accessed Jul 28, 2019).

(102) Dietrich, N.; Kentheswaran, K.; Ahmadi, A.; Teychené, J.; Bessière, Y.; Alfenore, S.; Laborie, S.; Bastoul, D.; Loubière, K.; Guigui, C.; Sperandio, M.; Barna, L.; Paul, E.; Cabassud, C.; Liné, A.; Hébrard, G. Attempts, Successes, and Failures of Distance Learning in the Time of COVID-19. J. Chem. Educ. 2020, 97 (9), 2448-2457. https://doi.org/10.1021/acs.jchemed.0c00717. (103) Rovner, S. L. Video Game Aims To Engage Students. Chem. Eng. News Archive 2006, 84 (15), 76-77. https://doi.org/10.1021/cen-v084n015.p076.

(104) Franco, J. Online Gaming for Understanding Folding, Interactions, and Structure. $J$. Chem. Educ. 2012, 89 (12), 1543-1546. https://doi.org/10.1021/ed200803e.

(105) Winter, J.; Wentzel, M.; Ahluwalia, S. Chairs!: A Mobile Game for Organic Chemistry Students To Learn the Ring Flip of Cyclohexane. J. Chem. Educ. 2016, 93 (9), 1657-1659. https://doi.org/10.1021/acs.jchemed.5b00872. 
834 (106) Cain, J.; Piascik, P. Are Serious Games a Good Strategy for Pharmacy Education? Am $835 J$ Pharm Educ 2015, 79 (4), 47. https://doi.org/10.5688/ajpe79447.

836 (107) Barr, M. Video Games Can Develop Graduate Skills in Higher Education Students: A 837 Randomised Trial. Computers \& Education 2017, 113, 86-97.

838 https://doi.org/10.1016/j.compedu.2017.05.016.

839 (108) Mayer, R. E.; Parong, J.; Bainbridge, K. Young Adults Learning Executive Function

840 Skills by Playing Focused Video Games. Cognitive Development 2019, 49, 43-50.

841 https://doi.org/10.1016/j.cogdev.2018.11.002.

842 (109) Smaldone, R. A.; Thompson, C. M.; Evans, M.; Voit, W. Teaching Science through

843 Video Games. Nature Chemistry 2016, 9, 97-102. https://doi.org/10.1038/nchem.2694.

844 (110) Isokawa, N.; Fueda, K.; Miyagawa, K.; Kanno, K. Demonstration of the Coagulation 845 and Diffusion of Homemade Slime Prepared Under Acidic Conditions without Borate. $J$.

846 Chem. Educ. 2015, 92 (11), 1886-1888. https://doi.org/10.1021/acs.jchemed.5b00272.

847 (111) O'Reilly, J. E. Fluorescence Experiments with Quinine. J. Chem. Educ. 1975, 52 (9), 848 610. https://doi.org/10.1021/ed052p610.

849 (112) Sacksteder, L.; Ballew, R. M.; Brown, E. A.; Demas, J. N.; Nesselrodt, D.; DeGraff,

850 B. A. Photophysics in a Disco: Luminescence Quenching of Quinine. J. Chem. Educ. 1990,

85167 (12), 1065. https://doi.org/10.1021/ed067p1065.

852 (113) Coleman, W. F. Featured Molecules: Quinine and Urea. J. Chem. Educ. 2003, 80 (10),

853 1219. https://doi.org/10.1021/ed080p1219.

854 (114) Froehlich, P. Fluorescence and Phosphoresence Spectroscopy: Physicochemical

855 Principles and Practice (Schulman, Stephen G.). J. Chem. Educ. 1979, 56 (1), A41.

856 https://doi.org/10.1021/ed056pA41.1.

857 (115) White, E. H.; Zafiriou, Oliver.; Kagi, H. H.; Hill, J. H. M. Chemilunimescence of

858 Luminol: The Chemcial Reaction. J. Am. Chem. Soc. 1964, 86 (5), 940-941.

859 https://doi.org/10.1021/ja01059a050.

860 (116) Chalmers, J. H.; Bradbury, M. W.; Fabricant, J. D. A Multicolored Luminol-Based

861 Chemiluminescence Demonstration. J. Chem. Educ. 1987, 64 (11), 969.

862 https://doi.org/10.1021/ed064p969.1.

863 (117) Martin, T.; Fleissner, J.; Milius, W.; Breu, J. Behind Crime Scenes: The Crystal

864 Structure of Commercial Luminol. Crystal Growth \& Design 2016, 16 (5), 3014-3018.

865 https://doi.org/10.1021/acs.cgd.6b00425.

866 (118) Game of Thrones

867 https://en.wikipedia.org/w/index.php?title=Game_of_Thrones\&oldid=906921790 (accessed

868 Jul 19, 2019).

869 (119) A Game of Thrones

870 https://en.wikipedia.org/w/index.php?title=A_Game_of_Thrones\&oldid=906455223

871 (accessed Jul 19, 2019).

872 (120) Zhu, B.; Feng, M.; Lowe, H.; Kesselman, J.; Harrison, L.; Dempski, R. E. Increasing

873 Enthusiasm and Enhancing Learning for Biochemistry-Laboratory Safety with an

874 Augmented-Reality Program. J. Chem. Educ. 2018, 95 (10), 1747-1754.

875 https://doi.org/10.1021/acs.jchemed.8b00116.

876 (121) Sanger, M. J. Flame Tests: Which Ion Causes the Color? J. Chem. Educ. 2004, 81

877 (12), 1776A. https://doi.org/10.1021/ed081p1776A.

$878 \quad$ (122) Breaking Bad

879 https://en.wikipedia.org/w/index.php?title=Breaking_Bad\&oldid=907809675 (accessed Jul

880 29, 2019).

881 (123) Fahy, D. The Chemist as Anti-Hero: Walter White and Sherlock Holmes as Case

882 Studies. In Hollywood Chemistry; ACS Symposium Series; American Chemical Society,

883 2013; Vol. 1139, pp 175-188. https://doi.org/10.1021/bk-2013-1139.ch015.

884 (124) Dextroamphetamine 
885 https://en.wikipedia.org/w/index.php?title=Dextroamphetamine\&oldid=907015456 (accessed 886 Jul 29, 2019).

887 (125) Cornely, K.; Bennett, N. Thalidomide Makes a Comeback: A Case Discussion

888 Exercise That Integrates Biochemistry and Organic Chemistry. J. Chem. Educ. 2001, 78 (6), 889 759. https://doi.org/10.1021/ed078p759.

890 (126) Coleman, W. F. Enantiomer Specificity in Pharmaceuticals. J. Chem. Educ. 2004, 81

891 (7), 981. https://doi.org/10.1021/ed081p981.

892 (127) Epstein, J. Weapons of Mass Destruction: It Is All about Chemistry. J. Chem. Educ.

893 2009, 86 (12), 1377. https://doi.org/10.1021/ed086p1377.

894 (128) Ober, J.; Krebs, T. Chemical Elements in Fantasy and Science Fiction. J. Chem. Educ. 895 2009, 86 (10), 1141. https://doi.org/10.1021/ed086p1141.

896 (129) Martí-Centelles, V.; Rubio-Magnieto, J. ChemMend: A Card Game To Introduce and 897 Explore the Periodic Table While Engaging Students' Interest. J. Chem. Educ. 2014, 91 (6), 898 868-871. https://doi.org/10.1021/ed300733w.

899 (130) Hoffman, A.; Hennessy, M. The People Periodic Table: A Framework for Engaging 900 Introductory Chemistry Students. J. Chem. Educ. 2018, 95 (2), 281-285.

901 https://doi.org/10.1021/acs.jchemed.7b00226.

902 (131) Chapman, K. A Disney Periodic Table Https://Kitchapman.Co.Uk/a-Disney-Periodic903 Table/ (accessed Jul 26, 2020).

904 (132) Osa, R. A. de la. Tabla Periódica DC

905 https://rodrigoalcarazdelaosa.me/blog/2020/07/16/tabla-periodica-dc/ (accessed Jul 26, 2020).

906 (133) Souto, M, Marvel Periodic Table

907 https://marvelperiodictable.blogspot.com/2020/07/1.html (accessed Jul 26, 2020).

908 (134) Likert, R. A Technique for the Measurement of Attitudes. Archives of Psychology

909 1932, $22 \quad 140,55-55$.

910 (135) Harrison, A. W. Lessons from "Spider-Man": How Video Games Could Change

911 College Science Education. The Conversation. 2019.

912 (136) Jimenez, M.; L. Bridle, H. Angry Pathogens, How to Get Rid of Them: Introducing

913 Microfluidics for Waterborne Pathogen Separation to Children. Lab on a Chip 2015, 15 (4),

914 947-957. https://doi.org/10.1039/C4LC00944D.

915 (137) Bernath, P. F. Spectra of Atoms and Molecules; Oxford University Press, 2005.

916 (138) Angry Birds (video game)

917 https://en.wikipedia.org/w/index.php?title=Angry_Birds_(video_game)\&oldid=914589232

918 (accessed Sep 8, 2019).

919 (139) Chia, M. C.; Sweeney, C. M.; Odom, T. W. Chemistry in Microfluidic Channels. J.

920 Chem. Educ. 2011, 88 (4), 461-464. https://doi.org/10.1021/ed1008624.

921 (140) Vangunten, M. T.; Walker, U. J.; Do, H. G.; Knust, K. N. 3D-Printed Microfluidics

922 for Hands-On Undergraduate Laboratory Experiments. J. Chem. Educ. 2020, 97 (1), 178-183.

923 https://doi.org/10.1021/acs.jchemed.9b00620.

924 (141) Teeter, C. E. An Introduction to Nuclear Power in a Freshman Chemistry Course. $J$.

925 Chem. Educ. 1970, 47 (3), 208. https://doi.org/10.1021/ed047p208.

926 (142) Rabbids Invasion

927 https://en.wikipedia.org/w/index.php?title=Rabbids_Invasion\&oldid=906885522 (accessed

928 Jul 19, 2019).

929 (143) Raving Rabbids

930 https://en.wikipedia.org/w/index.php?title=Raving_Rabbids\&oldid=903130009 (accessed Jul $93120,2019)$.

932 (144) Guglielmetti, R.; Meyer, R.; Dupuy, C. Synthesis of a Photochromic Benzothiazolinic Undergraduate Laboratory. J. Chem. Educ. 2001, 78 (5), 645. 
936 https://doi.org/10.1021/ed078p645.

937 (146) Piard, J. Influence of the Solvent on the Thermal Back Reaction of One Spiropyran. $J$. 938 Chem. Educ. 2014, 91 (12), 2105-2111. https://doi.org/10.1021/ed4005003.

939 (147) Poisson, L.; Raffael, K. D.; Soep, B.; Mestdagh, J.-M.; Buntinx, G. Gas-Phase

940 Dynamics of Spiropyran and Spirooxazine Molecules. J. Am. Chem. Soc. 2006, 128 (10),

941 3169-3178. https://doi.org/10.1021/ja055079s.

942 (148) Dragon Ball

943 https://en.wikipedia.org/w/index.php?title=Dragon_Ball\&oldid=914364416 (accessed Sep 8, 944 2019).

945 